\title{
Isolation and characterization of microsatellite markers in the African catfish Clarias gariepinus (Burchell, 1822)
}

\author{
P. GALBUSERA, F. A. VOLCKAERT, B. HELLEMANS and F. OLLEVIER \\ Katholieke Universiteit Leuven, Laboratory of Ecology and Aquaculture, Naamsestraat 59, B-3000 Leuven, Belgium
}

Received 15 January 1996; revision accepted 21 April 1996

Keywords: microsatellites, DNA, Clarias gariepinus, African catfish

The African catfish Clarias gariepinus is an economically important species, apart from being a model organism in research (Volckaert et al. 1994). Its natural distribution extends all over Africa and Asia Minor; it is cultured intensively and extensively in Africa, Europe and Asia (Huisman \& Richter 1987). Little is known about the genetic background of the natural populations and the cultured stocks. Specific highly polymorphic markers are required for example to assess the inbreeding level (Bentzen et al. 1991) associated with the aquaculture of this species (Van Der Bank et al. 1992).

Due to the relatively high polymorphism microsatellite loci may be used as markers in studies of parentage, quantitative genetics and population genetics (Tautz 1989). $(G T)_{n}$-repeats, in particular, prove to be highly abundant (Queller et al. 1993). We developed specific microsatellite primers for Clarias gariepinus in order to perform paternity tests and to characterize wild and domesticated populations. We report the isolation and characterization of seren $(G T)_{n}$ markers and their potential use in other catfish species.

The microsatellite primers were isolated through the production and screening of a library of short fragments of genomic DNA of Clarias gariepinus (Queller et al. 1993). After extraction of high-molecular-weight DNA, $50 \mu \mathrm{g}$ DNA of a single individual was restricted with three different restriction enzymes (HaeIII, RsaI and HincIII). The fragments were separated on a $1 \%$ low melting point agarose gel and the 300-800-bp fragments isolated. These fragments were ligated into a pUC18 vector. The ligation products were transformed in $\mathrm{DH} 5 \alpha$-competent cells ( $E$. coli; GIBCO BRL) which were plated on to agar plates. The resulting colonies were blotted on Hybond-N membranes which were hybridized with a synthetic $(G T)_{15}$ probe endlabelled with $\left[\gamma^{3}{ }^{32} \mathrm{P}\right] \mathrm{ATP}$. The colonies that hybridized were isolated and cultured in a liquid medium. The colonies were sequenced and primer sets were developed for the specific flanking regions of the microsatellite

Correspondence: Peter Galbusera. Tel.: + 32-16-323966. Fax: + 3216-324575. E-mail: peter.galbusera@bio.kuleuven.ac.be repeats. Fifty-three positive clones were sequenced (Sanger's dideoxy method; T7 DNA-polymerase kit from USB) of which 33 contained GT-repeats (39 arrays in total). A total of 10 different primer sets have been developed specific for Clarias gariepinus (Cga01-10).

Genomic DNA for genotyping was prepared using the phenol-chloroform extraction method or by boiling for $2 \mathrm{~h}$ in a 10\% Chelex solution (Chelex 100 resin from BIORAD). Initially random labelling with ${ }^{35} \mathrm{~S}$ was used to visualize the PCR-products (Weber \& May 1989). The final concentrations of the reagents in a volume of $12.5 \mu \mathrm{L}$ were as follows: $10-100 \mathrm{ng}$ of genomic DNA, $1 \times$ PCR-buffer $(75 \mathrm{mM}$ Tris- $\mathrm{HCl}$ pH 9.0, $20 \mathrm{mM}\left(\mathrm{NH}_{4}\right)_{2} \mathrm{SO}_{4}, 0.01 \%$ Tween 20$), 1 \mathrm{mM}$ $\mathrm{MgCl}_{2}, 15$ pmol of each primer, $75 \mu \mathrm{M}$ of dNTPs (-dATP), 0.25 units of Taq polymerase (Goldstar, Eurogentec S.A.) and $50 \mathrm{nmol}\left[\alpha^{-35} \mathrm{~S}\right] \mathrm{dATP}$ (ICN). A drop of mineral oil was added before PCR to prevent evaporation and $9 \mu \mathrm{L}$ of Stop-solution after PCR. The initial denaturation took 4 $\mathrm{min}$ at $94^{\circ} \mathrm{C}$ followed by 30 cycles $\left(9.4^{\circ} \mathrm{C}\right.$ for $45 \mathrm{~s}, 30 \mathrm{~s}$ at a specific annealing temperature as specified in Table 1 and $72{ }^{\circ} \mathrm{C}$ for $30 \mathrm{~s}$ ) and $10 \mathrm{~min}$ at $72{ }^{\circ} \mathrm{C}$ in a thermocycler (Triblock, Eurogentec S.A.).

After $5 \mathrm{~min}$ of denaturation at $93^{\circ} \mathrm{C}, 4-5 \mu \mathrm{L}$ of the PCRproducts were separated on a $6 \%$ denaturing polyacrylamide-gel at $30-50 \mathrm{~mA}$ during $2.5 \mathrm{~h}$ of vertical electrophoresis. After fixation and drying, the gel was exposed to a X-ray film during $48 \mathrm{~h}$. The alleles were scored by using a labelled marker (M13 sequencing reaction) whose size is known up to the base pair. We also used high-resolution $4 \%$ agarose (NuSieve GTG from FMC) gels in TBE buffer to separate PCR products (alleles) differing at least eight basepairs.

In order to avoid radioactivity but to maintain a high resolution, we currently apply 5'-fluorescently labelled primers (Fluos-Phosphororamidite, Eurogentec S.A.) to visualize PCR-products on a $7 \%$ acrylamide-gel (HydroLink) in an A.L.F. DNA Sequencer (Pharmacia Biotech). The gels can be reused once.

PCR conditions for seven of the 10 sets (Table 1) could be optimized to yield clear bands, whose sizes were in accordance with the sizes predicted by the sequence 
Table 1 Characterization of seven Clarias garicpinus (GT) -microsatellite primer sets, including locus name, repeat array, primer sequences, Genbank Accession number, specific annealing temperature, size-range of PCR-products and observed number of alleles ( $n=38$ individuals)

\begin{tabular}{|c|c|c|c|c|c|c|c|}
\hline Locus & Repeat array & Primer sequences $\left(5^{\prime} \rightarrow 3^{\prime}\right)$ & $\begin{array}{l}\text { Genbank } \\
\text { Accession } \\
\text { number }\end{array}$ & $\begin{array}{l}{\left[\mathrm{MgCl}_{2}\right]} \\
\text { in } \mathrm{mM}\end{array}$ & $\begin{array}{l}\text { Annealing } \\
\text { temp. }\left({ }^{\circ} \mathrm{C}\right)\end{array}$ & $\begin{array}{l}\text { Size range of } \\
\text { PCR product (bp) }\end{array}$ & $\begin{array}{l}\text { No. of } \\
\text { alleles }\end{array}$ \\
\hline Cga01 & $(\mathrm{GT})_{15}$ & $\begin{array}{l}\text { GGCTAAAAGAACCCTGTCTG } \\
\text { TACAGCGTCGATAAGCCAGG }\end{array}$ & U30862 & 1 & 59 & $92-104$ & 5 \\
\hline $\mathrm{CgaO2}$ & $(G T)_{10} \mathrm{~N}_{2}(\mathrm{GT})_{8}$ & $\begin{array}{l}\text { GCTAGTGTGAACGCAAGGC } \\
\text { ACCTCTGAGATAAAACACAGC }\end{array}$ & U30863 & 1 & 58 & $102-110$ & 5 \\
\hline $\mathrm{CgaO3}$ & $(G T)_{2 \mathrm{~J}}$ & $\begin{array}{l}\text { CACTTCTTACATTTGTGCCC } \\
\text { ACCTGTATTGATTCTTGCC }\end{array}$ & U30864 & 1 & 56 & $142-168$ & 13 \\
\hline Cga05 & $(G T)_{11} N_{2}(G T)_{2}$ & $\begin{array}{l}\text { TCCACATTAAGGACAACCACCG } \\
\text { TTTGCAGTTCACGACTGCCG }\end{array}$ & U30866 & 1.5 & 60 & $204-212$ & 5 \\
\hline Cga06 & $(\mathrm{GT})_{5} \mathrm{~N}_{2}(\mathrm{GT})_{9}$ & $\begin{array}{l}\text { CAGCTCGTGTTTAATTTGGC } \\
\text { TTGTACGAGAACCGTGCCAGG }\end{array}$ & U30867 & 1.5 & 60 & $134-142$ & 5 \\
\hline $\mathrm{Cga09}$ & $\begin{array}{l}(\mathrm{GA})_{3} \mathrm{~N}_{3}(\mathrm{GT})_{11} \mathrm{~N} \\
(\mathrm{GT})_{6} \mathrm{~N}_{2}(\mathrm{GT})_{4}\end{array}$ & $\begin{array}{l}\text { CGTCCACTTCCCCTAGAGCG } \\
\text { CCAGCTGCATTACCATACATGG }\end{array}$ & U30871 & 1 & 65 & $180-196$ & 7 \\
\hline Cga10 & $(G T)_{2} \mathrm{~N}_{2}(\mathrm{GT})_{15}$ & $\begin{array}{l}\text { GCTGTAGCAAAAATGCAGATGC } \\
\text { TCTCCAGAGATCTAGGCTGTCC }\end{array}$ & U30870 & 1 & 60 & $102-138$ & 14 \\
\hline
\end{tabular}

\begin{tabular}{llllllllll}
\hline \multirow{2}{*}{ Species } & Sample size & Cga01 & Cga02 & Cg03 & Cga05 & Cga06 & Cga09 & Cga10 \\
\cline { 2 - 9 } \cline { 3 - 8 } & Clarias anguillaris & 32 & 9 & 6 & 8 & 8 & 5 & 10 & 9 \\
$\begin{array}{l}\text { Clarias alluaudi } \\
\text { Heterobranchus }\end{array}$ & 1 & 2 & 2 & 2 & 1 & 1 & 2 & 2 \\
longifilis & 20 & 5 & 6 & 2 & 4 & 1 & 1 & 1 \\
\hline
\end{tabular}

Table 2 Number of alleles detected in three African catfish species after PCR amplification with seven microsatellite primer sets developed for Clarias gariepinus information. All of these primer sets produced PCR bands that were inherited in a Mendelian fashion (unpublished data).

The seven markers were used to analyse samples originating from Kenya (Lake Victoria), revealing a fairly high amount of allelic polymorphism (Table 1). The number of alleles per locus ranged from 5 to 14 and the heterozygosity from 43 to $89 \%$ (mean $61 \%$ ) for 38 samples analysed. The number of heterozygotes was as expected at Hardy-Weinberg equilibrium for most of the markers as calculated by the GENEPOP program (Raymond \& Rousset 1995). A significant deficit $(P<0.05)$ in heterozygotes at loci $\mathrm{Cga05}$ and $\mathrm{Cga09}$ might be, amongst others, due to substructuring of the sample (Wahlund effect) or the presence of null alleles.

In addition, the Clarias gariepinus primers amplified microsatellite loci in other species. A mean of eight alleles was amplified by all primers in $C$. anguillaris (Linnaeus) DNA (32 samples). All primer sets also amplified DNA, yielding PCR products of similar size, of Heterobranchus longifilis Valenciennes, 1840, (20 samples) and C. alluaudi (one single sample) (Table 2). However, some loci (Cga06,
09 and 10) appeared to be monomorphic in Heterobranchus longifilis. The possibility to use primer sets interspecifically has been demonstrated in other teleosts such as cyprinids (Zheng et al. 1995).

\section{Acknowledgements}

This research has been funded by the Commission of the European Community (project FAR AQ.3.765). We express our gratitude towards E. Zouros and C. Batargias for their support in isolating the microsatellite probes and to $\mathrm{R}$. Huybrechts, A. De Loof and R. Decorte for excellent laboratory facilities. Samples were collected by J.-F. Agnèse.

\section{References}

Bentzen P, Harris AS, Wright JM (1991) Cloning of hypervariable minisatellite and simple sequence microsatellite repeats for DNA fingerprinting of important aquacultural species of salmonids and tilapia. In: DNA fingerprinting: Approaches and Applications (eds Burke T, Dolf G, Jeffreys AJ, Wolff R), pp. 243-262. Birkhäuser Verlag, Basel.

Huisman EA, Richter CJJ (1987) Reproduction, grow'th, health control and aquacultural potential of the African catfish, 
Clarias garicpinus (Burchell 1822). Aquaculture, 63, 1-14.

Queller DC, Strassmann JE, Hughes CR (1993) Microsatellites and kinship. Trends in Ecology and Evolution, 8, 285-289.

Raymond M, Rousset F (1995) GENEPOP (Version 1. 2): Population genetics software for exact test and ecumenism. Journal of Heredity, 86, 248-249.

Tautz D (1989) Hypervariability of simple sequences as a general source for polymorphic DNA markers. Nucleic Acids Research, $17,6463-6471$.

Van Der Bank FH, Grobler JP, Du Preez HH (1992) A comparative biochemical genetic study of three populations of domesticated and wild African catfish (Clarias gariepinus). Comparative
Biochemistry and Physiology, 101B, 387-390.

Volckaert FA, Hellemans BA, Galbusera P, Ollevier F, Sekkali B Belayew A (1994) Replication, expression, and fate of foreign DNA during embryonic and larval development of the African catfish. Molecular Marine Biology and Biotechnology, 3 (2), 57-69.

Weber JL, May PE (1989) Abundant class of human DNA polymorphism which can be typed using the polymerase chain reaction. American Journal of Human Genetics, 44, 388-396.

Zheng W, Stacey NE, Coffin J, Strobeck C (1995) Isolation and characterisation of microsatellite loci in the goldfish Carassius auratus. Molecular Ecology, 4, 791-792. 